\title{
Dostępność historycznych parków
}

\author{
Kamila Lucyna Boguszewska \\ e-mail: kamila_boguszewska@interia.eu
}

Samodzielna Pracownia Architektoniczna

\begin{abstract}
Streszczenie: Nowoprojektowane budynki powinny być dostosowane do potrzeb wszystkich użytkowników, podobnie jak przestrzenie publiczne.

Problem pojawia się, kiedy mamy do czynienia z substancją zabytkową. Niektóre budynki lub przestrzenie ze względu na swoją specyfikę (uwarunkowania prawne, kontekst historyczny) są tego pozbawione, a ich dostosowanie jest po prostu bardzo trudne. Podobnie ma się rzecz w odniesieniu do przestrzeni historycznych parków towarzyszącym założeniom rezydencjonalnym.

Obecnie ta sytuacja ulega zmianie. Znaczące w tej materii okazują się środki unijne na rewaloryzację historycznych założeń, a możliwość ich pozyskania determinuje próby maksymalnego dostosowania tego typu parków do potrzeb wszystkich użytkowników.

W artykule przedstawione zostaną główne nurty i zasady stosowane w tego typu założeniach. Autor podejmie także próbę określenia granic tego typu działań. Szczegółowo przedstawione zostaną wybrane procesy zachodzące w przestrzeni historycznych parków (zarówno in plus jak i in minus) na przykładzie rozwiązań europejskich ze szczególnym uwzględnieniem takich krajów jak Francja oraz Polska.
\end{abstract}

Słowa kluczowe: dostępność, projektowanie uniwersalne, historyczne założenie ogrodowe

\section{Wstęp}

Przestrzenie zielone stanowią integralny fragment miast. Obecnie szacuje się, że zieleń zabytkowa w postaci parków rezydencjonalnych stanowi ponad $80 \%$ zasobu zieleni zabytkowej ${ }^{1}$. Od zawsze towarzyszyła ona pałacom i dworom, często też jej obszar przekraczał znacznie zabudowania dworskie czy folwarczne².

Szacuje się, że tylko w roku 1944 z obszaru Lubelszczyzny zniknęło 1700 majątków ziemskich, zaś 20000 dworów i pałaców zostało przejętych. Osiemdziesiąt procent z nich uległo zniszczeniu ${ }^{3}$.

W roku 1993 Ośrodek Ochrony Zabytkowego Krajobrazu, oszacował liczbę historycznych parków na $9182^{4}$. Obecnie w zbiorach Narodowego Instytutu Dziedzictwa figuruje dokumentacja 9024 parków z czego w samym województwie lubelskim mamy 601 historycznych założeń ogrodowych ${ }^{5}$, co stanowi niecałe $7 \%$ całości.

Wyżej przedstawione dane dotyczą założeń ogrodowych towarzyszącym rezydencjom jak i historycznej zieleni miejskiej. Skwery, zieleńce i parki wpisują się bowiem w tożsamość miejsca, stanowiąc istotny element infrastruktury. Jednak nie było tak zawsze. W przestrzeni historycznych miast nie przewidywano bowiem miejsc do zakładania terenów zieleni. Wynikało to niewielkich rozmiarów "starówek" oraz kosztów poszczególnych działek, które przeznaczane były w 100\% pod zabudowę. Nieliczne tereny zieleni, które sporadycznie zakładano (ławy darniowe, hortus coclusus), nie zaliczane były to przestrzeni publicznych i tym samym ich dostępność była

1 D. Sikora, The state of preservation of historic parks and gardens ane the reasons for their degradation/Stan zachowania i przyczyny degradacji parków i ogrodów zabytkowych w Polsce [w:] Czasopismo Techniczne - Architektura, zeszyt 5-A (10), rok 2014 (111), s. 270

2 E. Przesmycka, Lubelszczyzna wielokulturowość osadnictwa, budownictwa i architektury, Lublin 2008, s. 202

Ibid, s. 212

D. Sikora, The state of..., s. 267

Przedstawione dane pochodzą z dokumentacji ewidencyjnej w zbiorach Narodowego Instytutu Dziedzictwa z dnia 31.03.2014. 
przeznaczona jedynie dla określonej grupy użytkowników. Już w XVIII wieku część ogrodów warszawskich: Ogród Saski, Łazienki Królewskie, Ogród Krasińskich czy Ks. Podkomorzego udostępnianie były do użytku mieszkańcom Warszawy. Jednak dopiero za czasów rządów Królestwa Kongresowego rozpoczęto świadome i planowe działania projektowe służące zakładaniu ogrodów miejskich ${ }^{6}$. Są więc one stosunkowo młode bo datowane na przełom XVIII i XIX wieku. Ich kompozycja i funkcja wpłynęła w znaczący sposób na poprawę jakości życia w mieście będąc równocześnie nieodłącznym elementem kompozycji urbanistycznej całości. Plany XIX wiecznych ogrodów miejskich zaczęły różnić się znacząco w stosunku do ogrodów miejskich z XVIII wieku, które pod względem kompozycji nawiązywały do założeń towarzyszącym rezydencjom ${ }^{7}$.

W pierwszej połowie XIX wieku przeważająca część nowo zakładanych parków posiadała układ krajobrazowo-geometryczny. Ten nurt reprezentują między innymi parki: w Radomiu, (1824), Sandomierzu (1859), Lublinie - ogród Saski (1837). Pół wieku później parki miejskie uzyskują charakter parków krajobrazowych.

Wiek XIX i początek XX wpisuje kompleksy zieleni w planowane struktury urbanistyczne. Przykładem tego typu działań była realizacja Plant miejskich w Krakowie. Utworzono tam zieleniec miejski obejmujący około 35 ha. Decyzja o jego realizacji podjęta została przez rząd austriacki na początku XIX wieku, a jej przyczyną była chęć poprawy warunków bytowo-sanitarnych na obszarze Starego Miasta poprzez rozebranie murów obronnych oraz zasypanie fos. Projekt „zielonego pierścienia wokół miasta” został przygotowany przez Feliksa Radwańskiego i obejmował 3000 m długości trenów zieleni o szerokości 50-100 m².

Obecnie sposób kształtowania terenów zieleni oraz problem ich konserwacji (także historycznych) spoczywa w gestii władz miejskich i samorządowych. Urzędnicy próbują pozyskiwać pieniądze unijne na rewaloryzację historycznych założeń ogrodowych zarówno na wsi jak i w mieście. Społeczeństwo, świadome funkcji jaką spełnia zieleń, optuje za tworzeniem nowych przestrzeni zieleni czego przykładem są „zielone budżety obywatelskie" powstające w różnych miastach. Z punktu widzenia użytkowników zarówno nowo powstałe przestrzenie jak i te historyczne powinny być bezpieczne, funkcjonalne i dostępne dla wszystkich. Wpisuje się to w kontekst projektowania uniwersalnego.

\section{Stan badań}

Po wojnie w latach pięćdziesiątych tematyką zabytkowych założeń rezydencjonalnych w Polsce zajmowali się G. Ciołek, L. Majdecki oraz J. Bogdanowski. Zebrali oni i usystematyzowali informacje oraz zachowaną ikonografię dotyczącą polskich założeń rezydencjonalnych. Wraz ze współpracownikami sporządzili oni liczne ewidencje zabytkowych ogrodów, biorąc pod uwagę problematykę ich bieżącej konserwacji oraz procesu rewaloryzacji. Tematyką historycznych parków w województwie lubelskim zajmował się D. Fijałkowski i M. Ksieniak. W wyniku ich pracy powstała dokumentacja dotycząca stanu zachowania wiejskich parków Lubelszczyzny (1983) oraz dwutomowe opracowanie autorstwa M. Kseniaka $(1981,1983)$ dotyczące historii i stanu zachowania założeń dworskich i pałacowych zlokalizowanych wzdłuż rzeki Wieprz. Nie bez znaczenia do obecnego stanu wiedzy dotyczącego założeń rezydencjonalnych na Lubelszczyźnie są Dzieje Rezydencji na dawnych kresach Rzeczypospolitej a zwłaszcza tom II i VI w których opisane zostały wybrane założenia. O architekturze neogotyckiej Lubelszczyzny pisał J. Żywicki (1998), historią dworów wzdłuż rzeki Giełczwi zajmował się L. Świetlicki. O architekturze rezydencjonalnej pisała także I. Rolska - Boruch $(1999,2003)$ oraz E. Przesmycka $(2001,2008)$, zaś tematyką zabudowań folwarcznych zajmował się B. Kwiatkowski (2012). Od lat badania prowadzą różne ośrodki akademickie z Politechniką Wrocławską i Krakowską włącznie. Rokrocznie organizowane są także konferencje i seminaria dotyczące tej tematyki.

Problematyką uniwersalności rozwiązań architektonicznych w kontekście udostępniania przestrzeni wybudowanych dla wszystkich zajmuje się E. Kuryłowicz (1996, 2005), J. Budny (2009), K. Kowalski (2011, 2012). Duży zasób wiedzy dotyczącej wyżej wymienionej tematyki zawarty został w licznych aktach prawnych zarówno w USA jak i Wielkiej Brytanii: Americans with Disabilities Act, Standards for accesible design (1991, 2010), Dissability Discramination Act $(1995,2005)$. W standardach Building for Everyone. Inclusion, Acces and use 
(2002) przedstawione zostały główne standardy dotyczące planowania dostępności. Natomiast w rozdziale dotyczącym środowiska zewnętrznego i jego kształtowania (External environment and approach) przedstawione zostały główne zasady tworzenia dostępnej przestrzeni dla wszystkich. Pod uwagę brane są tam takie zagadnienia jak: kształtowanie ciągów komunikacji kołowej (projektowanie parkingów, przejść dla pieszych) i pieszej ze szczególnym uwzględnieniem rozwiązań materiałowych oraz odpowiednio projektowanych mebli ulicznych,

\section{Dostępność historycznych parków}

Dostępność definiowana jest jako "funkcja stosowania się do przepisów lub zestaw kryteriów, które charakteryzuja minimalny poziom rozwiązań stosowanych celem sprostania potrzebom ludzi niepetnosprawnych" ${ }^{9}$. Według profesor Ewy Kuryłowicz: nie należy stosować tego terminu zamiennie z terminem projektowania uniwersalnego, gdyż ten drugi jest pojęciem znacznie szerszym - wiążącym się ze "sztuką i praktyka projektowa" ${ }^{10}$.

Zarówno budynki jak i przestrzeń projektowana powinny więc być dostępne dla wszystkich. Problem pojawia się, kiedy mamy do czynienia z substancją zabytkową. Niektóre obiekty lub przestrzenie ze względu na swoją specyfikę (uwarunkowania prawne czy kontekst historyczny) są tego pozbawione, a ich dostosowanie bywa po prostu niemożliwe. Podobnie ma się rzecz w odniesieniu do przestrzeni historycznych parków towarzyszącym założeniom rezydencjonalnym. Podjęcie próby tworzenia większej dostępności historycznych terenów zieleni pojawia się podczas projektów rewaloryzacyjnych, które dają projektantom możliwość dostosowania ich przestrzeni do potrzeb wszystkich użytkowników.

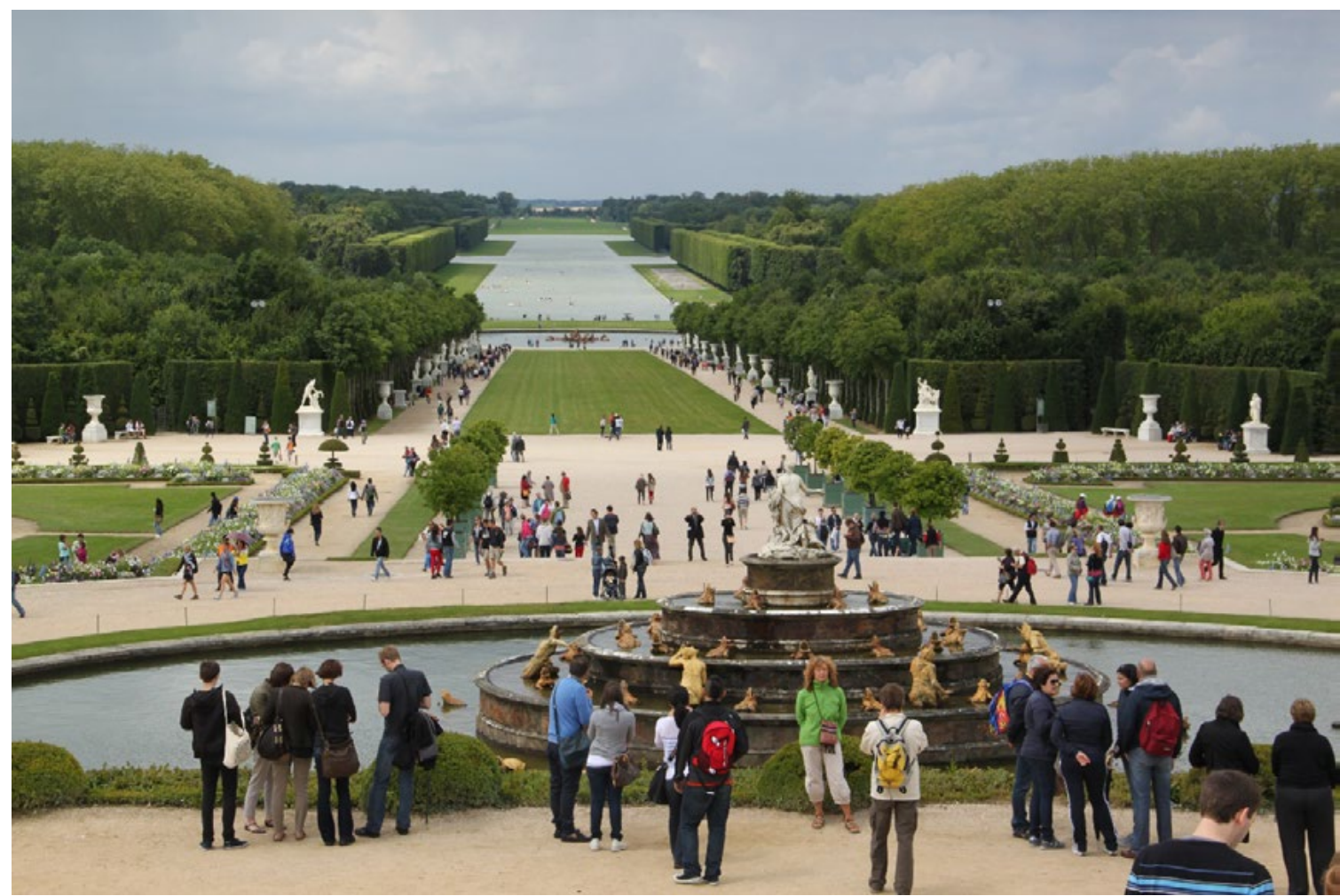

Ryc. 1. Wersal, widok na wielka oś. W tle rampa ogrodowa projektu Le Notra, (2012) fot. autor Versailles, view of the great axis. In the background garden ramp designed by Le Notre, (2012) photo by author

9 E. Kuryłowicz, Uniwersalność rozwiązań architektonicznych w kontekście otwierania środowiska wybudowanego dla wszystkich, jako wyraz i efekt postawy innowacyjnej - normalność w architekturze, Studia BAS, Nr 2(42) 2015, s. 207-208

10 Ibid, s. 208 
Dobrym przykładem są tutaj rozwiązania francuskie. W Wersalu stworzono trasy dostępne dla osób poruszających się na wózkach inwalidzkich. Ze względu na charakter barokowego założenia większa część ogrodu posiada płaskie ukształtowanie terenu dostępne dla osób z ograniczoną ruchomością (Ryc. 1, Ryc. 2b).

Plan parku i jego dostępności otrzymuje każdy zwiedzający co znacznie ułatwia planowanie zwiedzania. Możliwe jest także wynajęcie audiobooków.

Ze względu na duże odległości pomiędzy głównym budynkiem pałacu a Grand Trianon czy Petit Trianon kursuje "mini pociąg", który jest dostosowany do potrzeb osób z niepełnosprawnością ruchową (Ryc. 2a)

Tam gdzie to konieczne - w pałacu i parku pojawił się system ramp i wind umożliwiających komunikację omijając schody.

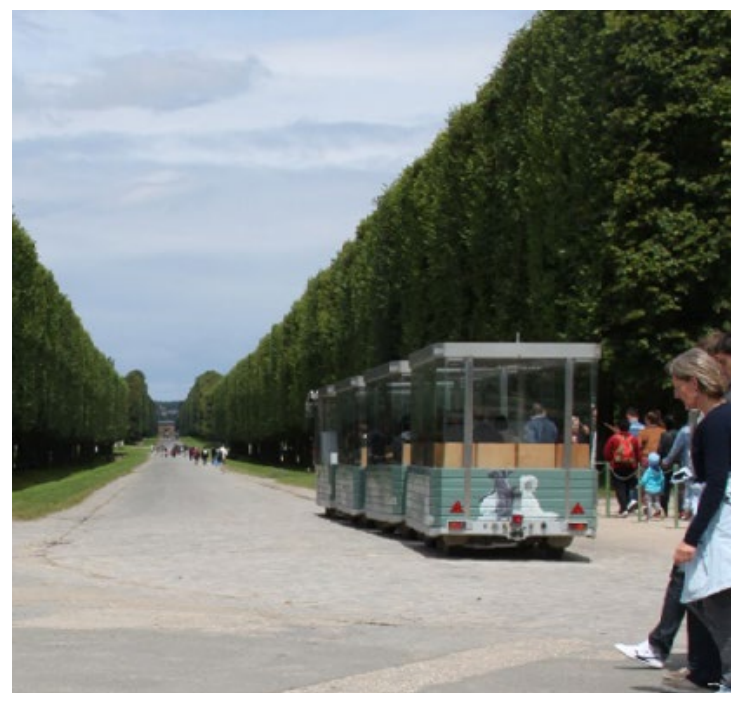

Ryc. 2a. "Mini pociąg" w Wersalu, fot. autor "Mini train" in Versailles, photo by author

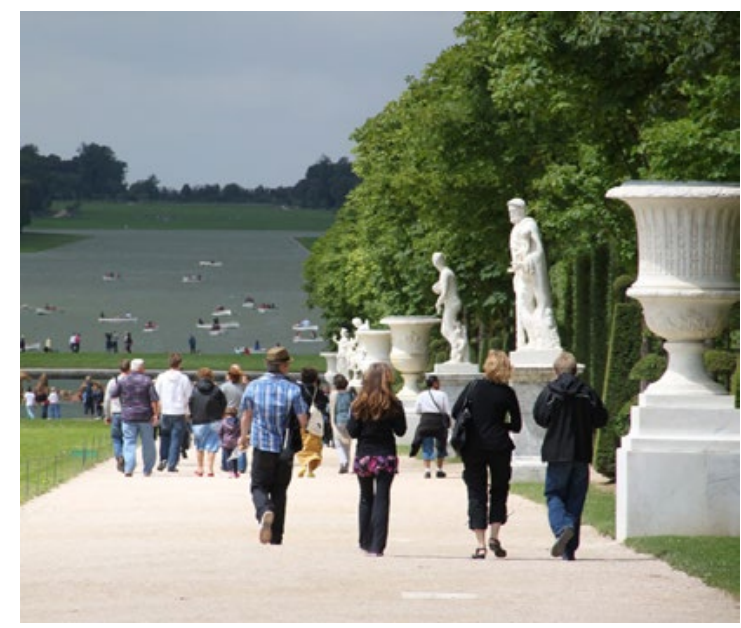

Ryc. 2b. Utwardzona nawierzchnia mineralna wzdłuż głównego traktu - wielkiej osi w Wersalu, (2012), fot. autor

Mineral paved surface along the main road - the major axis of Versailles (2012), photo by author

W Polsce ciekawym przykładem jest zrealizowany projekt rewaloryzacji parku w Żelazowej Woli wraz z obiektami obsługi turystów, administracji i zaplecza gospodarczego autorstwa biura Stelmach i Partnerzy. Rewaloryzowane założenie zostało zaprojektowane w latach 30-tych XX wieku przez architekta Franciszka Krzywdę Polkowskiego. Plan parku, o charakterze założenia modernistycznego, został silnie zgeometryzowany. Centralną część parku stanowi przebudowany na "dworek" dom urodzin Fryderyka Chopina. Do niego właśnie prowadzi główna ukośna aleja, która została poprowadzona asymetrycznie do całego założenia. Oprócz dworku w parku zaprojektowano także amfiteatr, wyspę, oraz część gospodarczo-usługową ${ }^{11}$.

Pod koniec XX wieku park znacznie podupadł.

W roku 2006 ogłoszono konkurs na rewaloryzację założenia w wyniku czego powstały trzy nowe obiekty architektoniczne z czego dwa - wpisane w ogrodzenie. Stanowią je transparentne - przeszklone pawilony pełniące funkcję wejściową, informacyjną i restauracyjną. Zaplecze ogrodowe umieszczono po przeciwległej stronie parku. Architekci zachowali detale architektoniczne zaprojektowane przez Polkowskiego, wprowadzając tylko niezbędne uzupełnienia ${ }^{12}$.

W wyniku rewaloryzacji park został także dostosowany do potrzeb osób niepełnosprawnych. Główną nawierzchnią parkową jest utwardzona nawierzchnia mineralna ze stalowymi obrzeżami, stanowiąca idealną nawierzchnię dla osób poruszających się na wózkach inwalidzkich. Oprócz niej zachowano modernistyczne detale Polkowskiego - elementy małej architektury - pergole, fragmenty nawierzchni - otoczaki umieszczone. Wymienione zostały jednak wszystkie elementy małej architektury wraz z oświetleniem (Ryc. 3). Przestrzeń parku oświetlona została jedynie niskim latarniami parkowymi. 
W przestrzeni parku pojawił się także wolno stojący drewniany pawilon. Mieści on sanitariaty dostosowane do potrzeb osób niepełnosprawnych. Obiekt umiejscowiony w niewielkim obniżeniu został skomunikowany z głównym ciągiem pieszym za pomocą schodów i ramp o małym procentowym spadku (Ryc. 3)
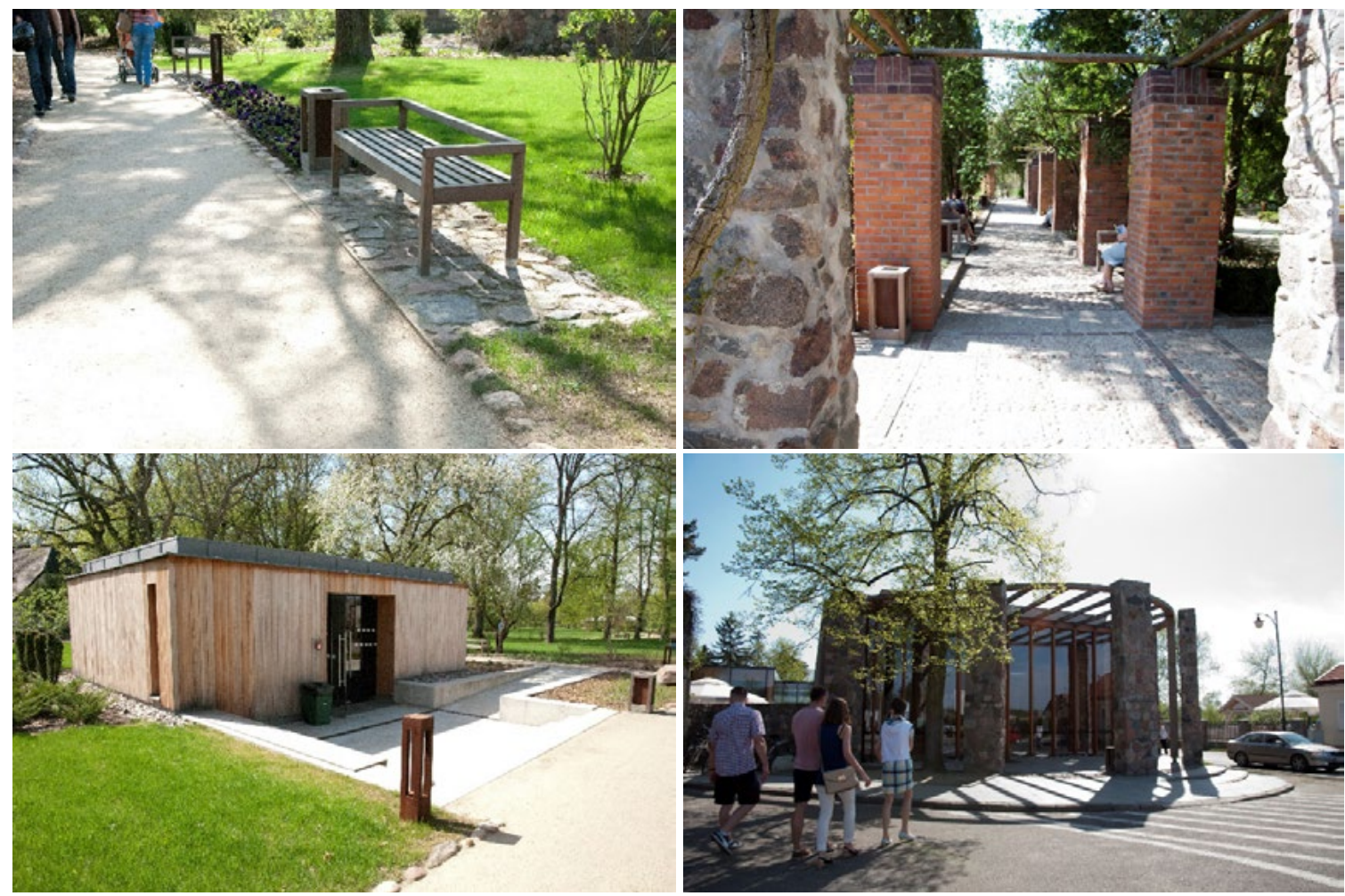

Ryc. 3. Zespół dworsko-parkowy w Żelazowej Woli, zróżnicowane nawierzchnie oraz nowoprojektowane pawilony, 2012, fot autor

Manor house complex in Zelazowa-Wola, different pavements and newly-designed pavillions, 2012, photo by author

W przestrzeni parku, podobnie jak w Wersalu, został zamontowany , "ukryty” w roślinności, system nagłośnienia, przez który puszczana jest muzyka Fryderyka Chopina. Nowoprojektowane pawilony wpisane zostały częściowo w ogrodzenie. Obiekty te dostosowano do potrzeb osób niepełnosprawnych. Częściowo zniwelowane zostały stopnie i krawężniki prowadzące do głównego budynku wejściowego do parku (Ryc. 4).

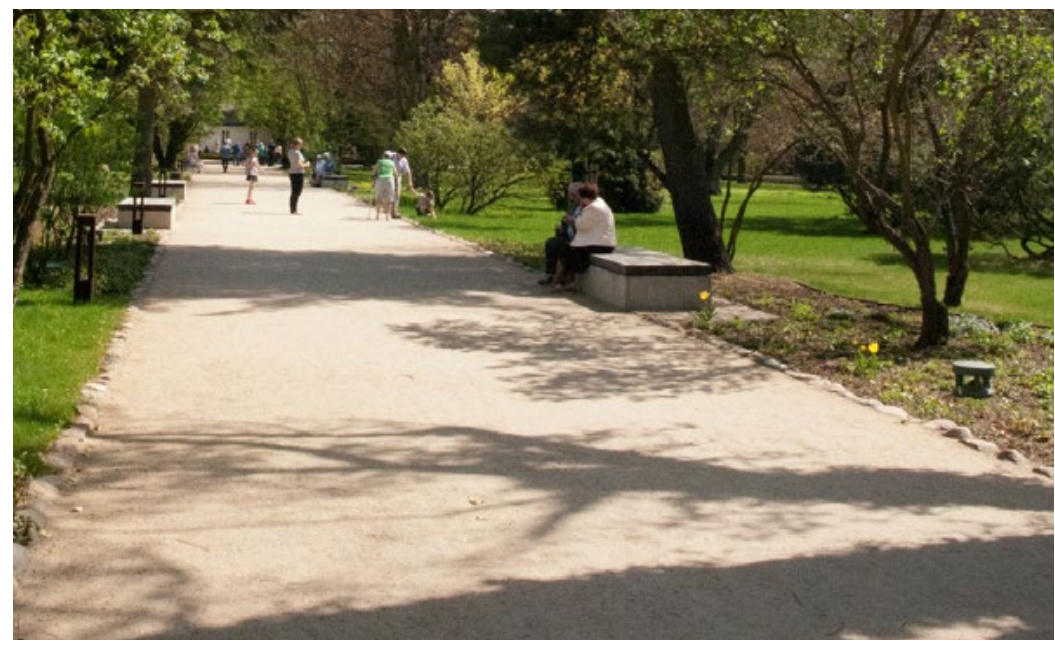

Ryc. 4. Elementy nagłośnienia (prawy dolny róg fotografii) w parku w Żelazowej Woli, 2012, fot autor

The elements of the sound system in park in Zelazowa Wola, 2012, photo by author 
Zespół pałacowo-parkowy w Nieborowie był własnością rodziny Radziwiłłów. Założenie ogrodowe posiada charakter barokowego układu regularnego. Ostateczną jego formę ukształtował w XVIII wieku Szymon Bogumił Zug. Obecnie budynek pałacu pełni rolę muzeum, zaś park udostępniony jest zwiedzającym. Przestrzeń parku została wygrodzona. Ogród nie posiada identyfikacji wizualnej ani ścieżek dla osób niewidomych lub słabo widzących. Plan barokowego parku został jedynie wyeksponowany na ogrodzeniu, jednak nie jest on dostosowany do potrzeb wszystkich użytkowników. W parku brakuje także oświetlenia. W przeważającej części ogrodu zastosowano nawierzchnie mineralne i zwykłe drogi gruntowe (Ryc. 5).
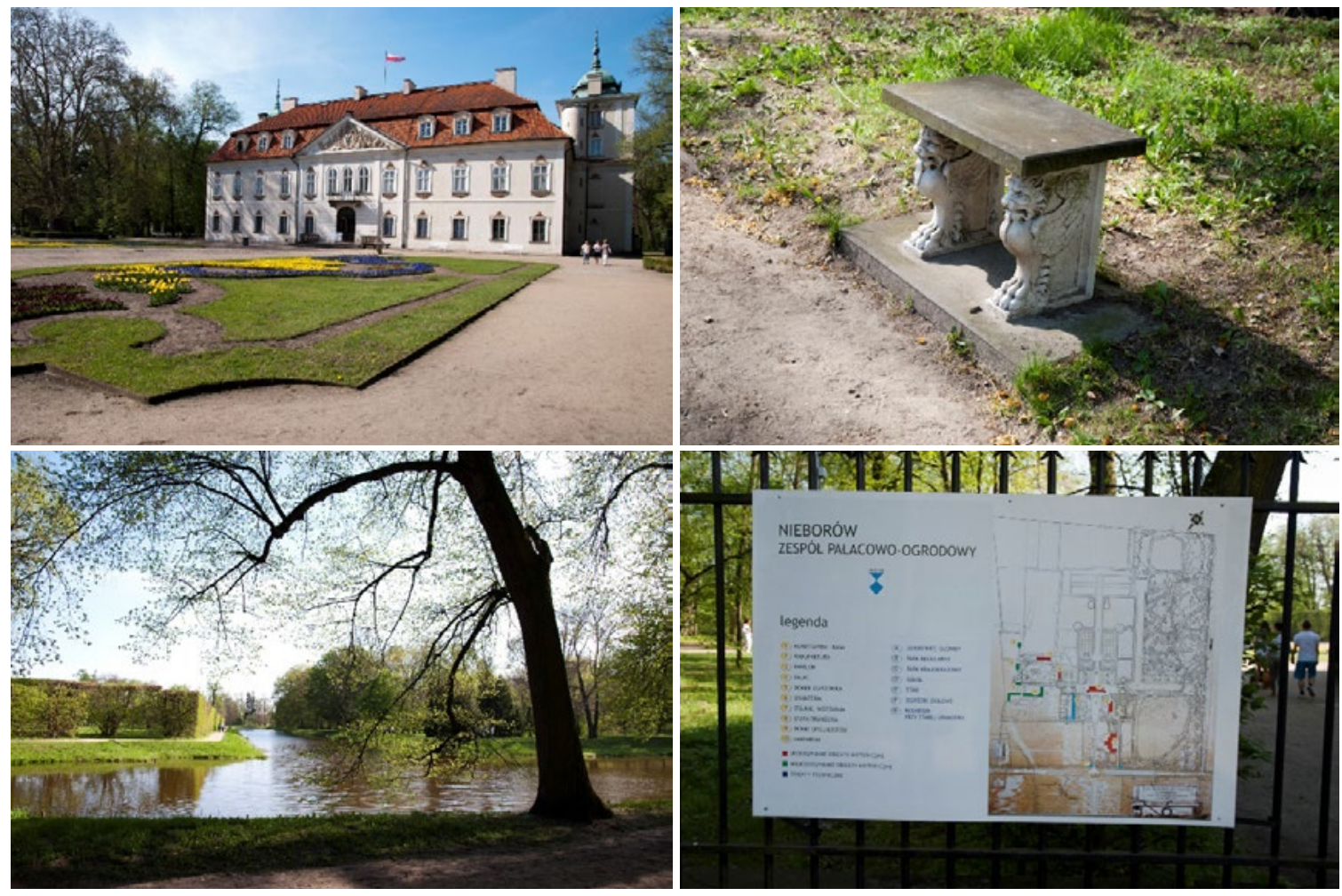

Ryc. 5. Zespół pałacowo-parkowy w Nieborowie, pałac oraz elementy małej architektury 2012, fot. autor Palace - park complex in Nieborów, palace and objects of small architecture 2012, photo by author

Jednym z bardziej znanych zespołów pałacowo-parkowych w Województwie Lubelskim jest założenie rezydencjonalne w Lubartowie. Całość prezentuje układ "entre cour et jardin". W części centralnej przed "cour $d^{\prime}$ honneur" - dziedzińcem honorowym znajduje się pałac, oranżeria usytuowana jest w północno-zachodniej części parku. Obecnie w budynku pałacu mieści się Urząd Miasta zaś park udostępniony jest jego mieszkańcom.

W 1949 przeprowadzono została rekonstrukcję parku według projektu Gerarda Ciołka. Założeniu nadano charakter francuskiego parku geometrycznego co miało nawiązywać do czasów największej świetności, kiedy majątek znajdował się w posiadaniu rodu Sanguszków.

Obecnie na dawnym cour d'honneur zlokalizowany został parking.

Przestrzeń parku krajobrazowego nie posiada oświetlenia. W części ogrodowej zastosowano nawierzchnię mineralną z obrzeżami betonowymi. Wzdłuż głównych układów komunikacyjnych rozmieszczone zostały "historyzujące" ławki (Ryc. 6). 

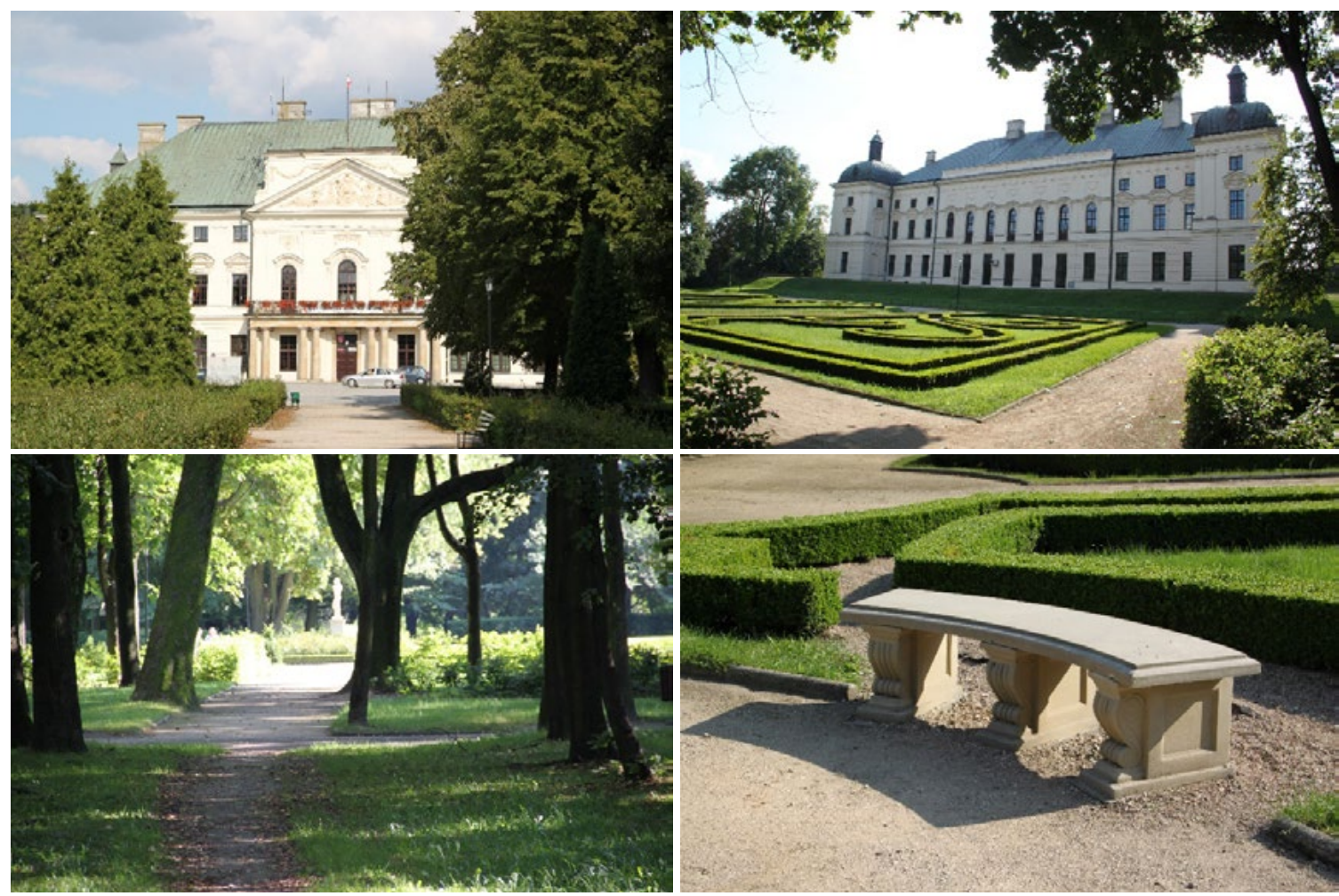

Ryc. 6. Zespół pałacowo-parkowy w Lubartowie, pałac, nawierzchnie i elementy małej architektury 2012, fot. autor Palace-park complex in Lubartów, palace, pavements and objects of small architecture 2012 photo by author

Z pałacem w Lubartowie nierozerwalnie związane jest założenie pałacowo-parkowe w Kozłówce. Oba zespoły połączone zostały ze sobą za pomocą alei lipowej.

Majątek ten ${ }^{13}$ największy swój rozkwit przeżywał, gdy jego właścicielem był Konstanty Zamoyski - twórca Ordynacji Kozłowieckiej oraz jego spadkobiercy Adam Zamoyski, a później jego syn Aleksander.

Obecnie nieprzerwanie od 1977 roku zespół pałacowo-parkowy pełni funkcję muzealną. Zwiedzającym udostępniony jest budynek pałacu wraz z oficynami i parowozownią oraz przestrzeń parku wraz z rozarium.

O ile neobarokowy park jest dostępny do potrzeb osób niepełnosprawnych o tyle sam budynek pałacu jest dostosowany jedynie częściowo.

Nawierzchnie zastosowane w parku to przede wszystkim kostka granitowa - na dziedzińcu honorowym oraz utwardzone nawierzchnie mineralne w części ogrodowej. Park nie posiada oświetlenia. Podobnie jak w Lubartowie brakuje systemu identyfikacji wizualnej oraz ścieżek dla osób niewidomych lub słabowidzących (Ryc. 7).

13 Od roku 1903 dobra kozłowieckie stały się ordynacją rodową. Oznaczało to, że majątek był niepodzielny, niezbywalny, zaś dziedziczenie wyłączone było ze zwykłego prawa spadkowego, (za: M. Kozaczka, Działalność gospodarcza w Ordynacji Kozłowieckiej Zamoyskich w okresie między wojennym, [w:] Ziemiaństwo na Lubelszczyźnie, Materiały I sesji naukowej zorganizowanej w Muzeum w Zamoyskich w Kozłówce 8-9 czerwca 2000, opracowała Róża Maliszewska, Muzeum Zamoyskich w Kozłówce 2001, s. 254). 

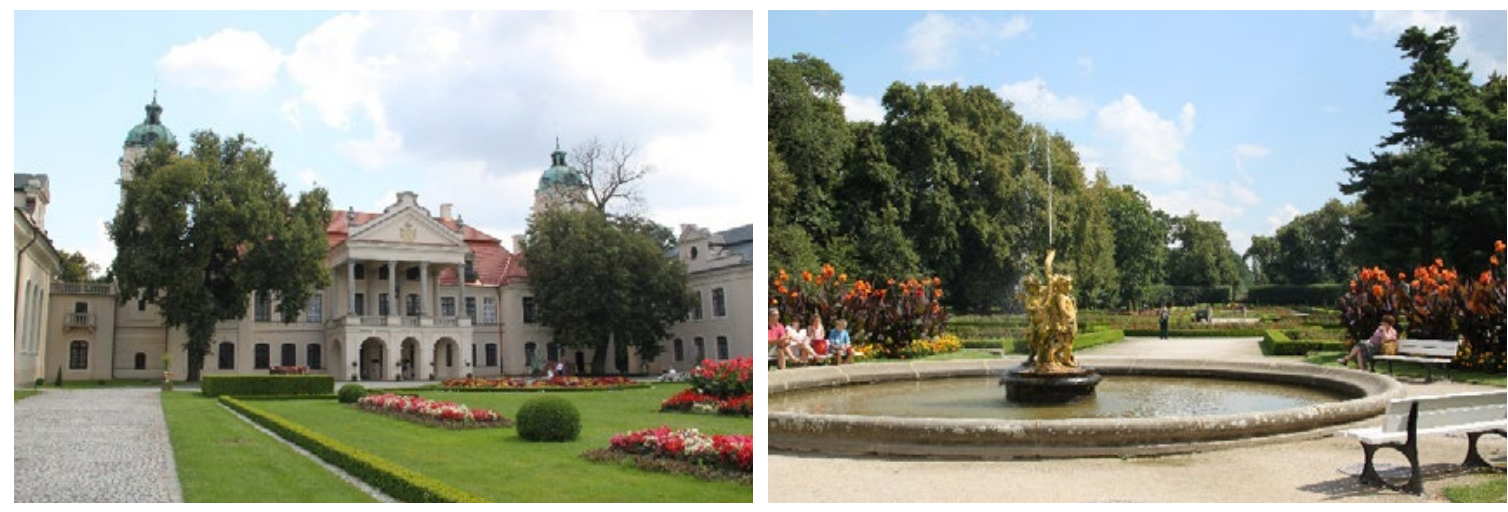

Ryc. 7. Zespół pałacowo-parkowy w Kozłówce, pałac oraz część ogrodowa 2012, fot autor

Palace-park complex in Kozłówka, palace and garden behind the building 2012, photo by author

Innym przykładem jest zespół dworsko-parkowy w Romanowie mieszczący Muzeum im. Józefa Ignacego Kraszewskiego. Park wraz ze dworem dostępny jest dla wszystkich zwiedzających. Do dworu, wyniesionego nieco do poziomu gazonu, od strony frontowej prowadzą dwie rampy wkomponowane w podjazd.

\section{Wnioski}

Możliwości dostosowania przestrzeni historycznych parków do potrzeb wszystkich użytkowników należy rozważać indywidualnie w zależności od charakteru i problematyki danego założenia.

Kompleksowe podejście - tworzenie pełnej dostępności możliwe jest jedynie podczas projektów rewaloryzacyjnych. Znaczące w tej materii okazują się środki unijne na rewaloryzację historycznych założeń, a możliwość ich pozyskania determinuje próby maksymalnego dostosowania tego typu parków do potrzeb wszystkich użytkowników.

Nie znaczy to jednak, że niemożliwym jest tworzenie dostępności za pomocą prostych i tanich rozwiązań.

W przyszłości należy opracować szczegółowy plan tego typu działań. Pod uwagę należy brać takie zagadnienia jak: możliwość dojazdu, rozwiązania materiałowe dotyczące stosowanych nawierzchni i elementów małej architektury - ramp, siedzisk itd.. Istotnym elementem jest próba zaprojektowania spójnego systemu identyfikacji wizualnej, ścieżek dla osób słabowidzących w przestrzeni parku, a także nasadzeń roślinnych w postaci ogrodów i rabat sensorycznych.

Analizując powyższe przykłady nie jest to rzecz niemożliwa. Bardzo dużo zależy od świadomości projektanta. Olbrzymia odpowiedzialność spoczywa także na rękach władz konserwatorskich.

\section{Piśmiennictwo}

[1] Building for Everyone. Inclusion, Access and use, Dublin, National Disability Authority, 2002.

[2] G. Ciołek, Ogrody polskie, Arkady, Warszawa 1978.

[3] K. Kowalski, Planowanie dostępności - polskie uwarunkowania prawne i praktyka, Niepetnosprawność - zagadnienia, problemy, rozwiązania, $\mathrm{Nr} 1 / 2013$.

[4] M. Kozaczka, Działalność gospodarcza w Ordynacji Kozłowieckiej Zamoyskich w okresie między wojennym, [w:] Ziemiaństwo na Lubelszczyźnie, Materiały I sesji naukowej zorganizowanej w Muzeum w Zamoyskich w Kozłówce 8-9 czerwca 2000, opracowała Róża Maliszewska, Muzeum Zamoyskich w Kozłówce 2001.

[5] E. Kuryłowicz, Uniwersalność rozwiązań architektonicznych w kontekście otwierania środowiska wybudowanego dla wszystkich, jako wyraz i efekt postawy innowacyjnej - normalność w architekturze, Studia BAS, Nr 2(42) 2015.

[6] L. Majdecki, Historia ogrodów, od XVIII wieku do wspótczesności, T. 2, PWN, Warszawa 2008.

[7] E. Przesmycka, Lubelszczyzna wielokulturowość osadnictwa, budownictwa i architektury, Lublin 2008. 
[8] D. Sikora, The state of preservation of historic parks and gardens ane the reasons for their degradation/Stan zachowania i przyczyny degradacji parków i ogrodów zabytkowych w Polsce [w:] Czasopismo Techniczne - Architektura, 2014, r. 111, z. 5-A.

[9] Grzegorz Stiasny, Rozbudowa Muzeum Fryderyka Chopina w Żelazowej Woli, [w:]Architektura murator, nr 191, $08,2010$.

\section{Availability of historic parks}

Summary: Newly designed buildings must be adapted to the needs of all users, as well as public spaces. The problem arises when we are dealing with historic material. Some buildings or spaces due to its specificity (such as legal conditions - the historical context) are deprived of this. Sometimes their adaptation is very difficult.. The same is true with regard to the historic parks accompanying residence. Currently, this situation is changing. Possibility of obtaining EU funds, determine the maximum adjustment of historic parks to meet the needs of all users. The article presents the main trends and rules applicable to this type of assumptions. Author also makes an attempt to define the limits of this type of action. The article, in detail way, presents selected processes in the historic parks (both in plus and in minus) on the example of European solutions with special emphasis on countries such as France and Poland.

Keywords: accessibility, universal design, historical assumption 